\title{
Butyrolactones Derivatives from the Fermentation Products of an Endophytic Fungus Aspergillus versicolor
}

\author{
Yan-qing Ye, ${ }^{\dagger,+}$ Cong-Fang Xia, ${ }^{\dagger}$ Juan-Xia Yang, ${ }^{\dagger}$ Yu-Chun Yang, ${ }^{\dagger}$ Ying Qin, ${ }^{\dagger}$ \\ Xue-Mei Gao, ${ }^{\dagger}$ Gang Du, ${ }^{\dagger}$ Xue-Mei Li ${ }^{\dagger,+, *}$ and Qiu-Fen $\mathrm{Hu}^{\dagger, *}$
}

${ }^{\dagger}$ Key Laboratory of Chemistry in Ethnic Medicinal Resources, State Ethnic Affairs Commission \& Ministry of Education, Yunnan University of Nationalities, Kunming 650031,P.R. China. E-mail: huqiufena@aliyun.com

*Yunnan Academy of Tobacco Science, Kunming 650106, P.R. China. *E-mail: xmli@cyats.com

Received June 13, 2014, Accepted July 7, 2014

\begin{abstract}
Two new butyrolactones, asperphenol A (1) and B (2), together with four known butyrolactones (3-6) were isolated from the fermentation products of an endophytic fungus Aspergillus versicolor. Their structures were elucidated by spectroscopic methods including extensive 1D- and 2D-NMR techniques. Compounds 1-6 were also tested for their anti-tobacco mosaic virus (anti-TMV) activities. The results showed that compound $\mathbf{2}$ exhibited high anti-TMV activity with inhibition rate of $46.7 \%$. The other compounds also exhibited potential anti-TMV activities with inhibition rates in the range of $21.8-28.4 \%$.
\end{abstract}

Key Words : Butyrolactones, Aspergillus versicolor, Structure elucidation, Anti-TMV activity

\section{Introduction}

The genus Aspergillus (Moniliaceae), with over 180 species, has attracted considerable attention as a rich source of alkaloids, terpenoids, xanthones, and polyketides, some of which showed antifungal, antibacterial, antifouling, and cytotoxic activities. ${ }^{1-3}$ Butyrolactones were mainly found as metabolites from fungi and high plants in nature. ${ }^{4}$ They appeal to medicinal chemists because of their pronounced pharmacological effects including antibacterial, ${ }^{5,6}$ anti-tumor, ${ }^{7,8}$ anti-inflammatory, ${ }^{9,10}$ anti-virus, ${ }^{11,12}$ and the like.

In previous studies, some butyrolactones were isolated from the fermentation products of fungus Aspergillus. ${ }^{13-16}$ With the aim of searching for new bioactive metabolites from the fermentation products of microbe, an endophytic Aspergillus versicolor were isolated from the rhizome of Paris polyphylla var. yunnanensis, collected in Shizhong, Yunnan province, P. R. China, and the chemical constituents of it fermentation products were investigated. As a result, two new (1-2) and four known (4-6) butyrolactones were isolated. The structures of new compounds were elucidated on the basis of a comprehensive analysis of the ${ }^{1} \mathrm{H}$ and ${ }^{13} \mathrm{C}$ NMR. In addition, the anti-tobacco mosaic virus (anti-TMV) active of compounds 1-6 was evaluated. The details of the isolation, structure elucidation, and anti-tobacco mosaic virus active of the compounds isolated are reported in this article.

\section{Results and Discussion}

The fermented substrate was extracted with $70 \%$ aqueous acetone. The extract was subjected repeatedly to column chromatography on silica gel, RP-18, and semi-preparative RP-HPLC separation to afford compounds 1-6. The structures of 1-6 were shown in Figure 1 , and the ${ }^{1} \mathrm{H}$ and ${ }^{13} \mathrm{C}$ NMR data of the compounds $\mathbf{1}$ and $\mathbf{2}$ were listed in Table 1. By comparing with the literature, the known compounds
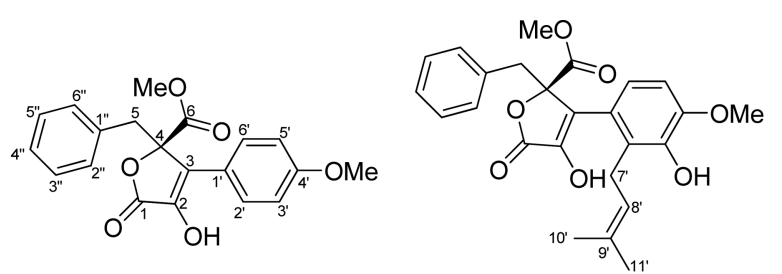

2

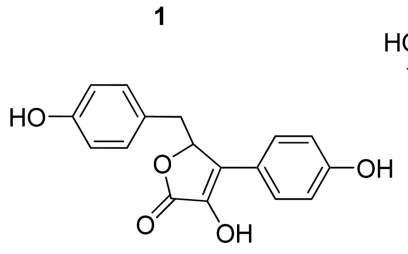

4

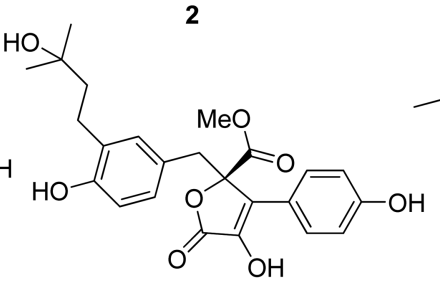

5

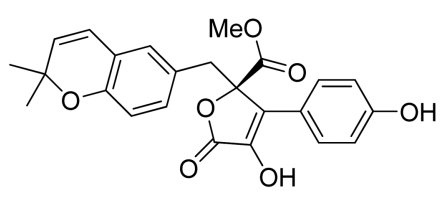

3

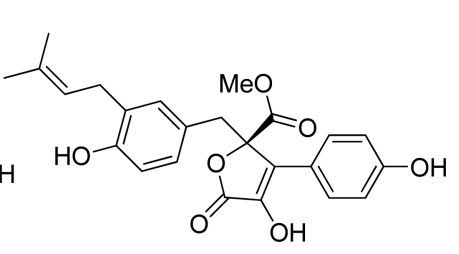

6

Figure 1. The structures of compounds 1-6. 
Table $1 .{ }^{1} \mathrm{H}$ and ${ }^{13} \mathrm{C}$ NMR Data of compounds $\mathbf{1}$ and $\mathbf{2}(\delta$ in ppm, 500 and $125 \mathrm{MHz}$ )

\begin{tabular}{|c|c|c|c|c|}
\hline \multirow{2}{*}{ No. } & \multicolumn{2}{|c|}{ Compound $\mathbf{1}^{a}$} & \multicolumn{2}{|c|}{ Compound $\mathbf{2}^{b}$} \\
\hline & $\delta_{\mathrm{C}}(\mathrm{m})$ & $\delta_{\mathrm{H}}(\mathrm{m}, J, \mathrm{~Hz})$ & $\delta_{\mathrm{C}}(\mathrm{m})$ & $\delta_{\mathrm{H}}(\mathrm{m}, J, \mathrm{~Hz})$ \\
\hline 1 & $169.3 \mathrm{~s}$ & & $169.1 \mathrm{~s}$ & \\
\hline 2 & $137.7 \mathrm{~s}$ & & $138.3 \mathrm{~s}$ & \\
\hline 3 & $128.1 \mathrm{~s}$ & & $128.6 \mathrm{~s}$ & \\
\hline 4 & $85.6 \mathrm{~s}$ & & $85.0 \mathrm{~s}$ & \\
\hline 5 & $39.3 \mathrm{t}$ & $3.53,3.62 \mathrm{~d}(14.5)$ & $37.9 \mathrm{t}$ & $3.35,3.43 \mathrm{~d}(14.6)$ \\
\hline 6 & $169.9 \mathrm{~s}$ & & $170.0 \mathrm{~s}$ & \\
\hline $1^{\prime}$ & $121.8 \mathrm{~s}$ & & $123.2 \mathrm{~s}$ & \\
\hline $2^{\prime}$ & $130.6 \mathrm{~d}$ & $7.61 \mathrm{~d}(8.8)$ & $134.5 \mathrm{~s}$ & \\
\hline $3^{\prime}$ & $116.0 \mathrm{~d}$ & $6.91 \mathrm{~d}(8.8)$ & $143.9 \mathrm{~s}$ & \\
\hline $4^{\prime}$ & $160.3 \mathrm{~s}$ & & $150.0 \mathrm{~s}$ & \\
\hline $5^{\prime}$ & $116.0 \mathrm{~d}$ & $6.91 \mathrm{~d}(8.8)$ & $112.9 \mathrm{~d}$ & $6.96 \mathrm{~d}(8.5)$ \\
\hline $6^{\prime}$ & $130.6 \mathrm{~d}$ & $7.61 \mathrm{~d}(8.8)$ & $119.2 \mathrm{~d}$ & $7.62 \mathrm{~d}(8.5)$ \\
\hline $7^{\prime}$ & & & $27.3 \mathrm{t}$ & $3.60, \mathrm{~d}(6.8)$ \\
\hline $8^{\prime}$ & & & $124.1 \mathrm{~d}$ & $5.19, \mathrm{t}(6.8)$ \\
\hline $9^{\prime}$ & & & $131.4 \mathrm{~s}$ & \\
\hline $10^{\prime}$ & & & $18.1 \mathrm{q}$ & $1.81 \mathrm{~s}$ \\
\hline $11^{\prime}$ & & & $25.0 \mathrm{q}$ & $1.62 \mathrm{~s}$ \\
\hline $1^{\prime \prime}$ & $132.8 \mathrm{~s}$ & & $132.4 \mathrm{~s}$ & \\
\hline $2^{\prime \prime}, 6^{\prime \prime}$ & $130.4 \mathrm{~d}$ & $6.84 \mathrm{~d}(8.0)$ & $130.5 \mathrm{~d}$ & $6.86 \mathrm{~d}(8.0)$ \\
\hline $3^{\prime \prime}, 5^{\prime \prime}$ & $127.9 \mathrm{~d}$ & $7.13 \mathrm{dd}(7.6,8.0)$ & $127.8 \mathrm{~d}$ & $7.15 \mathrm{dd}(7.6,8.0)$ \\
\hline $4^{\prime \prime}$ & $127.2 \mathrm{~d}$ & $7.10 \mathrm{~d}(7.6)$ & $127.2 \mathrm{~s}$ & $7.18 \mathrm{~d}(7.6)$ \\
\hline $4^{\prime}-\mathrm{OMe}$ & $55.9 \mathrm{q}$ & $3.82 \mathrm{~s}$ & $56.0 \mathrm{q}$ & $3.82 \mathrm{~s}$ \\
\hline 6-OMe & $53.5 \mathrm{q}$ & $3.77 \mathrm{~s}$ & $53.1 \mathrm{q}$ & $3.79 \mathrm{~s}$ \\
\hline $3 '-\mathrm{OH}$ & & & & $12.47 \mathrm{~s}$ \\
\hline
\end{tabular}

$a_{\text {in } \mathrm{CDCl}_{3} .}{ }_{\text {in }}\left(\mathrm{CD}_{3}\right)_{2} \mathrm{CO}$

were identified as aspernolide E (3), ${ }^{15}$ 4-(4-hydroxyphenyl)5-(4-hydroxyphenylmethyl)-2-hydroxyfurane-2-one (4), ${ }^{16}$ aspernolide B (5), ${ }^{14}$ and butyrolactone I (6). ${ }^{17}$

Asperphenol A (compound 1) was obtained as white solid. The molecular formula $\mathrm{C}_{20} \mathrm{H}_{18} \mathrm{O}_{6}$ of $\mathbf{1}$ was determined by HRESIMS which showed pseudomolecular ion peaks $[\mathrm{M}+\mathrm{Na}]^{+}$at 377.1006 (calcd. 377.1001). The IR spectrum showed the presence of ester/lactone carbonyl at 1740 and $1730 \mathrm{~cm}^{-1}$, hydroxyl were evident at $3342 \mathrm{~cm}^{-1}$, and the presence of the absorptions at 1610,1521 , and $1496 \mathrm{~cm}^{-1}$ was suggestive of aromaticity in the molecule. The ${ }^{1} \mathrm{H}$ NMR signals revealed the presence of a monosubstituted benzene moiety $\left(\delta_{\mathrm{H}} 6.84 \mathrm{~d}, J=8.0,2 \mathrm{H} ; 7.13\right.$, dd, $J=7.6,8.0,2 \mathrm{H}$; 7.10, d, $J=7.6,1 \mathrm{H})$, a 1,4-disubstituted benzene moiety $\left(\delta_{\mathrm{H}}\right.$ $7.61, \mathrm{~d}, J=8.8,2 \mathrm{H} ; 6.91, \mathrm{~d}, J=8.8,2 \mathrm{H}$ ), a methylene protons $\left(\delta_{\mathrm{H}} 3.53,3.62\right.$, d each, $\left.J=14.5\right)$, and two methoxy proton $\left(\delta_{\mathrm{H}} 3.79 \mathrm{~s}\right.$ and $\left.3.82 \mathrm{~s}\right)$. Its ${ }^{13} \mathrm{C}$ NMR showed the presence of a monosubstituted benzene moiety $\left[\delta_{\mathrm{C}} 132.8 \mathrm{~s}, 130.4 \mathrm{~d}(2 \mathrm{C})\right.$, $127.9 \mathrm{~d}(2 \mathrm{C}) 127.2 \mathrm{~d}$ ], a 1,4-disubstituted benzene moiety [ $\left.\delta_{\mathrm{C}} 121.8 \mathrm{~s}, 130.6 \mathrm{~d}(2 \mathrm{C}), 116.0 \mathrm{~d}(2 \mathrm{C}) 160.3 \mathrm{~s}\right]$ moiety, a methoxycarbonyl group $\left(\delta_{\mathrm{C}} 169.9 \mathrm{~s}, 53.5 \mathrm{q}\right)$, a ester carbonyl $\left(\delta_{\mathrm{C}} 169.3 \mathrm{~s}\right)$, a pair of olefenic carbon $\left(\delta_{\mathrm{C}} 137.7 \mathrm{~s}\right.$ and 128.1 $\mathrm{s})$, a methylene carbon $\left(\delta_{\mathrm{C}} 39.3 \mathrm{t}\right)$, and a quaternary carbon $\left(\delta_{\mathrm{C}} 85.6 \mathrm{~s}\right)$. The molecular formula $\mathrm{C}_{20} \mathrm{H}_{18} \mathrm{NaO}_{6}$ requires 12 degrees of unsaturation. The presence of two aromatic rings accounts for eight, while two carbonyls and one olefenic
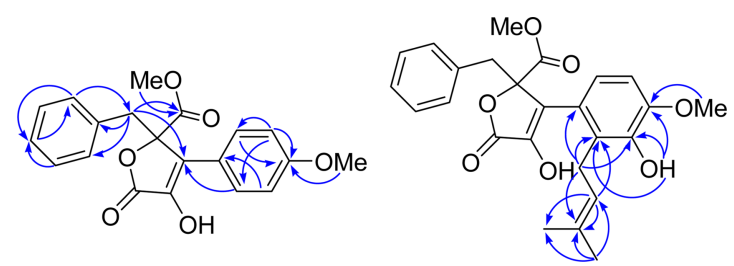

Figure 2. Key HMBC ( $\triangleleft)$ correlations of (1) and (2).

carbons account for another three, which makes a total of eleven degrees of unsaturation. Therefore 1 must possessing one aliphatic ring in addition to two aromatic rings. The tropical carbon signals $\left(\delta_{\mathrm{C}} 169.3 \mathrm{~s}, 137.7 \mathrm{~s}, 128.1 \mathrm{~s}, 85.6 \mathrm{~s}\right.$, $39.3 \mathrm{t}, 169.9 \mathrm{~s}$ ) indicated that compound $\mathbf{1}$ has the butyrolactone skeleton. ${ }^{15-17}$ A detailed comparison of the NMR data of 1 with these of methyl 3-(4-hydroxyphenyl)-4-oxidanyl-5-oxidanylidene-2-(phenylmethyl) furan-2-carboxylate (7) ${ }^{18}$ revealed that the only difference due to a hydroxy group at C-4' in $\mathbf{7}$ was substituted by a methoxy group in $\mathbf{1}$. This difference was supported by the HMBC correlations (Figure 2) from 4'-OMe $\left(\delta_{\mathrm{H}} 3.82\right)$ to $\mathrm{C}-4^{\prime}\left(\delta_{\mathrm{C}} 160.3\right)$. Therefore, the structure of $\mathbf{1}$ was assigned as shown.

Compound $\mathbf{2}$ was also isolated as a pale yellow gum, and its molecular formula was determined as $\mathrm{C}_{25} \mathrm{H}_{26} \mathrm{NaO}_{7}$ through HRESI-MS analysis (pseudomolecular ion $[\mathrm{M}+\mathrm{Na}]^{+}$at $\mathrm{m} / \mathrm{z}$ 461.1571). The ${ }^{1} \mathrm{H}$ and ${ }^{13} \mathrm{C}$ NMR data of 2 were very similar to these of 1 (see Table 1) at the positions of C-1 C -6 and $\mathrm{C}-1$ " $\sim \mathrm{C}-6$ ". The maior difference resulted from the the chemical siift varietions on the other aromatic ring $\left(\mathrm{C}^{-} 1^{\prime} \sim\right.$ $\left.\mathrm{C}-6^{\prime}\right)$, and the appearance of an additional prenyl group $\left[\delta_{\mathrm{C}}\right.$ $27.3 \mathrm{t}, 124.1 \mathrm{~d}, 131.4 \mathrm{~s}, 18.1 \mathrm{q}, 25.0 \mathrm{q} ; \delta_{\mathrm{H}} 3.60 \mathrm{~d}(J=6.8)$, $5.19 \mathrm{t}(J=6.8), 1.81 \mathrm{~s}$, and $1.62 \mathrm{~s}]$ and a phenolic hydroxy group $\left(\delta_{\mathrm{H}} 12.47 \mathrm{~s}\right)$. These indicated that the additional prenyl group and phenolic hydroxy group were located at this aromatic ring. Long-range HMBC correlations of $\mathrm{H}-7^{\prime}\left(\delta_{\mathrm{H}}\right.$ $3.60)$ to $\mathrm{C}-1^{\prime}\left(\delta_{\mathrm{C}} 123.2\right), \mathrm{C}-2^{\prime}\left(\delta_{\mathrm{C}} 134.5\right), \mathrm{C}-3^{\prime}\left(\delta_{\mathrm{C}} 143.9\right)$ were observed in $\mathbf{2}$. This indicated that the prenyl group was attached to $\mathrm{C}-2^{\prime}$. The HMBC correlations of methoxy protons $\left(\delta_{\mathrm{H}} 3.82\right)$ with $\mathrm{C}-4^{\prime}\left(\delta_{\mathrm{C}} 150.0\right)$ revealed that the methoxy group were located at $\mathrm{C}-4^{\prime}$. One phenolic hydroxy group located at C-3' were supported by the HMBC correlations of the phenolic hydroxy proton signal $\left(\delta_{\mathrm{H}} 12.47\right)$ with $\mathrm{C}-2^{\prime}\left(\delta_{\mathrm{C}}\right.$ $134.5), \mathrm{C}-3^{\prime}\left(\delta_{\mathrm{C}} 143.9\right)$ and $\mathrm{C}-4^{\prime}\left(\delta_{\mathrm{C}} 150.0\right)$. The typical ${ }^{1} \mathrm{H}$ NMR signals of the aromatic protons, $\mathrm{H}-5\left(\delta_{\mathrm{H}} 6.96, \mathrm{~d}, J=\right.$ $8.5)$ and H-6 $\left(\delta_{\mathrm{H}} 8.06, \mathrm{~d}, J=8.5\right)$ also supported the above substituent positions. Thus, the structure of $\mathbf{2}$ was established, and gives the trivail name of asperphenol $\mathrm{B}$.

Since some butyrolactones are known to exhibit potential anti-virus activities, ${ }^{11,12}$ compounds 1-6 were tested for their anti-TMV activities. The inhibitory activities of compounds 1-6 against TMV replication were tested using the half-leaf method. ${ }^{19}$ Ningnanmycin, a commercial product for plant disease in China, was used as a positive control. The antiviral inhibition rates of compounds 1-6 at the concentration of $20 \mu \mathrm{M}$ were listed Table 2 . The results showed that compound 2 exhibited high anti-TMV activity with inhibition rate of $46.7 \%$. The inhibition rate is higher than that of 
Table 2. TMV infection inhibition activities of compounds 1-6

\begin{tabular}{cccc}
\hline Compounds & $\begin{array}{c}\text { Inhibition rates } \\
(\%)\end{array}$ & Compounds & $\begin{array}{c}\text { Inhibition rates } \\
(\%)\end{array}$ \\
\hline $\mathbf{1}$ & $22.5 \pm 3.6$ & $\mathbf{5}$ & $28.4 \pm 3.2$ \\
$\mathbf{2}$ & $46.7 \pm 3.0$ & $\mathbf{6}$ & $24.3 \pm 2.8$ \\
$\mathbf{3}$ & $25.2 \pm 2.8$ & ningnamycin & $30.6 \pm 3.4$ \\
$\mathbf{4}$ & $21.8 \pm 2.4$ & & \\
\hline
\end{tabular}

All results are expressed as mean $\pm \mathrm{SD} ; \mathrm{n}=3$ for all groups.

positive control. The other compounds also showed potential anti-TMV activities with inhibition rates in the range of $21.8-28.4 \%$, respectively.

\section{Experimental}

General Experimental Procedures. Optical rotations were measured with a Horiba SEPA-300 polarimeter. UV spectra were obtained using a Shimadzu UV-2401A spectrophotometer. 1D and 2D NMR spectra were recorded on a DRX-400 or 500 NMR spectrometers with TMS as internal standard. Unless otherwise specified, chemical shifts $(\delta)$ are expressed in ppm with reference to the solvent signals. HRESIMS was performed on a VG Autospec-3000 spectrometer. Semipreparative HPLC was performed on a Shimadzu LC-8A preparative liquid chromatograph with Zorbax PrepHT GF $(21.2 \mathrm{~mm} \times 25 \mathrm{~cm})$ or Venusil MP $\mathrm{C}_{18}(20 \mathrm{~mm} \times 25 \mathrm{~cm})$ columns. Column chromatography was performed using silica gel (200-300 mesh, Qing-dao Marine Chemical, Inc., Qingdao, People's Republic of China), Lichroprep RP-18 gel (40-63 $\mu \mathrm{m}$, Merck, Darmstadt, Germany), and MCI gel (75-150 $\mu \mathrm{m}$, Mitsubishi Chemical Corporation, Tokyo, Japan). The fractions were monitored by TLC, and spots were visualized by heating silica gel plates sprayed with $5 \% \mathrm{H}_{2} \mathrm{SO}_{4}$ in $\mathrm{EtOH}$.

Fungal Material. The culture of Aspergillus versicolor was isolated from the rhizome of Paris polyphylla var. yunnanensis collected from Shizhong, Yunnan province, People's Republic of China, in 2007. The strain was identified by one of authors (Gang Du) based on the analysis of the ITS sequence. It was cultivated at room temperature for 7 days on potato dextrose agar at $28^{\circ} \mathrm{C}$. Agar plugs were inoculated into $250 \mathrm{~mL}$ Erlenmeyer flasks each containing $100 \mathrm{~mL}$ potato dextrose broth and cultured at $28^{\circ} \mathrm{C}$ on a rotary shaker at $180 \mathrm{rpm}$ for five days. Large scale fermentation was carried out in 200 Fernbach flasks $(500 \mathrm{~mL})$ each containing $100 \mathrm{~g}$ of rice and $120 \mathrm{~mL}$ of distilled $\mathrm{H}_{2} \mathrm{O}$. Each flask was inoculated with $5.0 \mathrm{~mL}$ of cultured broth and incubated at $25^{\circ} \mathrm{C}$ for 45 days.

Extraction and Isolation. The fermented substrate (10.8 $\mathrm{kg})$ was extracted four times with $70 \% \mathrm{MeOH}(4 \times 10 \mathrm{~L})$ at room temperature and filtered. The crude extract ( $287 \mathrm{~g})$ was applied to silica gel (200-300 mesh) column chromatography, eluting with a $\mathrm{CHCl}_{3}-\mathrm{CH}_{3} \mathrm{OH}$ gradient system $(9: 1,8: 2,7: 3$, $6: 4,5: 5)$, to give six fractions A-E. The further separation of fraction $\mathrm{A}(9: 1,22.6 \mathrm{~g})$ by silica gel column chromatography, eluted with $\mathrm{CHCl}_{3}-\left(\mathrm{CH}_{3}\right)_{2} \mathrm{CO}(9: 1,8: 2,7: 3,6: 4,1: 1)$, yielded mixtures A1-A5. Fraction A1 $(9: 1,8.6 \mathrm{~g})$ was subjected to silica gel column chromatography and preparative HPLC (68\% methanol, flow rate $12 \mathrm{~mL} / \mathrm{min})$ to give $2(22.5 \mathrm{mg})$ and 3 (15.2 mg). Fraction A2 (8:2, $4.6 \mathrm{~g})$ was separated by silica gel column chromatography and preparative HPLC $(63 \% \mathrm{MeOH}$, flow rate $12 \mathrm{~mL} / \mathrm{min})$ to give $\mathbf{5}(11.5 \mathrm{mg})$ and 6 (14.2 mg). Fraction A3 (7:3, $4.6 \mathrm{~g})$ was separated by silica gel column chromatography and preparative HPLC (58\% $\mathrm{MeOH}$, flow rate $12 \mathrm{~mL} / \mathrm{min})$ to give $1(11.5 \mathrm{mg})$ and 4 (14.2 mg).

Anti-TMV Assays. The Anti TMV activities were tested using the half-leaf method, and ningnanmycin, a commercial product for plant disease in China, was used as a positive control.

TMV (U1 strain) was obtained from the Key Laboratory of Tobacco Chemistry, Yunnan Academy of Tobacco Science. The virus was multiplied in Nicotiana tabacum cv. K326 and purified as previously described. ${ }^{20}$ The concentration of TMV was adjusted to $20 \mathrm{mg} / \mathrm{mL}$ as determined by UV absorption. [virus concentration $=\left(\mathrm{A}_{260} \times\right.$ dilution ratio $\left.) / E_{1 \mathrm{~cm}}^{0.1 \%, 260 \mathrm{~nm}}\right]$. The purified virus was kept at $-20{ }^{\circ} \mathrm{C}$ and diluted to $32 \mu \mathrm{g} /$ $\mathrm{mL}$ with $0.01 \mathrm{M}$ PBS before use.

Nicotiana glutinosa plants were cultivated in an insectfree greenhouse. Experiments were conducted when the plants grew to 5- to 6-leaf stage. The tested compounds were dissolved in DMSO and diluted with distilled $\mathrm{H}_{2} \mathrm{O}$ to the required concentrations. A solution of equal concentration of DMSO was used as negative control; and ningnanmycin was used as positive control.

For the Half-Leaf Method, the virus was mixed with a solution of the test compound for $30 \mathrm{~min}$ before inoculated on the left side of a leaf of $N$. glutinosa, whereas the right side of the leaf was inoculated with a mixture of DMSO and virus as a control. The local lesion numbers were recorded 34 days after inoculation. Three leaf blades were used for each compound. The inhibition rates were calculated according to the formula: Inhibition Rate $(\%)=[(\mathrm{C}-\mathrm{T}) / \mathrm{C}] \times 100 \%$, where $\mathrm{C}$ is the average number of local lesions in the control and $\mathrm{T}$ is the average number of local lesions in the treated leaves.

Asperphenol A (1): $\mathrm{C}_{20} \mathrm{H}_{18} \mathrm{O}_{6}$, obtained as white amorphous powder; $[\alpha]_{\mathrm{D}}^{24.8}+63.2(\mathrm{c} 0.20, \mathrm{MeOH})$; UV $(\mathrm{MeOH})$ $\lambda_{\max }(\log \varepsilon): 210$ (4.18), 236 (3.38), 287 (3.62) nm; IR (KBr) $v_{\max } 3342$, 3020, 2970, 2938, 1740, 1730, 1610, 1521, 1496, 1435, 1382, 1263, 1180, 1120, 1065, 1022, 921, 876, 763 $\mathrm{cm}^{-1} ;{ }^{1} \mathrm{H}$ and ${ }^{13} \mathrm{C}$ NMR (500 and $125 \mathrm{MHz}$, in $\mathrm{CDCl}_{3}$ ) see Table 1; ESIMS (positive ion mode) $m / z 377[\mathrm{M}+\mathrm{Na}]^{+}$; HRESIMS (positive ion mode) $\mathrm{m} / z \quad 377.1006[\mathrm{M}+\mathrm{Na}]^{+}$ (calcd 377.1001 for $\mathrm{C}_{20} \mathrm{H}_{18} \mathrm{NaO}_{6}$ ).

Asperphenol B (2): $\mathrm{C}_{25} \mathrm{H}_{26} \mathrm{O}_{7}$, obtained as white amorphous powder; $[\alpha]_{\mathrm{D}}^{24.8}+79.8(\mathrm{c} 0.20, \mathrm{MeOH})$; UV $(\mathrm{MeOH})$ $\lambda_{\max }(\log \varepsilon): 210$ (4.32), 246 (3.51), 302 (3.74) nm; IR (KBr) $v_{\max } 3467,3026,2982,2921,1738,1727,1610,1532,1487$, 1430, 1395, 1270, 1176, 1118, 1069, 1025, 947, 859, 774 $\mathrm{cm}^{-1}$; ${ }^{1} \mathrm{H}$ and ${ }^{13} \mathrm{C}$ NMR see Table 1 (500 and $125 \mathrm{MHz}$, in $\left(\mathrm{CD}_{3}\right)_{2} \mathrm{CO}$ ); ESIMS (positive ion mode) $\mathrm{m} / z 461[\mathrm{M}+\mathrm{Na}]^{+}$; HRESIMS (positive ion mode) $\mathrm{m} / z$ 461.1571 $[\mathrm{M}+\mathrm{Na}]^{+}$ (calcd 461.1576 for $\mathrm{C}_{25} \mathrm{H}_{26} \mathrm{NaO}_{7}$ ). 
Acknowledgments. This research was supported by the National Natural Science Foundation of China (No. 21462051), the excellent Scientific and Technological Team of Yunnan High School (2010CI08), the Yunnan University of Nationalities Green Chemistry and Functional Materials Research for Provincial Innovation Team (2011HC008), and Open Research Fund Program of Key Laboratory of Ethnic Medicine Resource Chemistry (Yunnan University of Nationalities) (2010XY08).

\section{References}

1. Sun, L. L.; Shao, C. L.; Chen, J. F.; Guo, Z. Y.; Fu, X. M.; Chen, M.; Chen, Y. Y.; Li, R.; Voogd, N. J.; She, Z. G.; Lin, Y. C.; Wang, C. Y. Bioorg. Med. Chem. Lett. 2012, 22, 1326-1329.

2. Wang, Y.; Zheng, J. K.; Liu, P. P.; Wang, W.; Zhu, W. M. Mar. Drugs. 2011, 8, 1368-1378.

3. He, F.; Sun, Y. L.; Liu, K. S.; Zhang, X. Y.; Qian, P. Y.; Wang, Y. F.; Qi, S. H. J. Antibiot. 2012, 65, 109-111.

4. Kumar, S.; Garg, R.; Kabra, A. World. J. Pharm. Res. Tech. 2013, $1,131-142$.

5. Wang, W.; Kim, H.; Nam, S. J.; Rho, B. J.; Kang, H. J. Nat. Prod. 2012, 75, 2049-2054.

6. Centko, R. M.; Ramon-Garcia, S.; Taylor, T.; Patrick, B. O.; Thompson, C. J.; Miao, V. P.; Andersen, R. J. J. Nat. Prod. 2012, $75,2178-2182$

7. Li, D. H.; Zhu, T. J.; Liu, H. B.; Fang, Y. C.; Gu, Q. Q.; Zhu, W. M. Arch. Pharm. Res. 2006, 29, 624-626.
8. Wang, X. J.; Xu, H. W.; Guo, L. L.; Zheng, J. X.; Xu, B.; Guo, X.; Zheng, C. X.; Liu, H. M. Bioorg. Med. Chem. Lett. 2011, 21, 3074-3077.

9. Boukouvalas, J.; Loach, R. P. J. Org. Chem. 2008, 73, 8109-8112.

10. Khokra, S. L.; Monga, J.; Husain, A.; Vij, M.; Saini, R. Med. Chem. Res. 2013, 22, 5536-5544.

11. Gao, H. Q.; Guo, W. Q.; Wang, Q.; Zhang, L. Q.; Zhu, M. L.; Zhu, T. J.; Gu, Q. Q.; Wang, W.; Li, D. H. Bioorg. Med. Chem. Lett. 2013, 23, 1776-1778.

12. Zhang, H. J.; Van Hung, N.; Cuong, N. M.; Soejarto, D. D.; Pezzuto, J. M.; Fong, H. H. S.; Tan, G. T. Planta. Med. 2005, 71, 452-457.

13. Haritakun, R.; Rachtawee, P.; Chanthaket, R.; Boonyuen, N.; Isaka, M. Chem. Pharm. Bull. 2010, 58, 1545-1548.

14. Parvatkar, R. R.; Souza, C.; Tripathi, A.; Naik, C. G. Phytochemistry 2009, 70, 128-132.

15. Niu, X. M.; Dahse, H. M.; Menzel, K. D.; Lozach, O.; Walther, G.; Meijer, L.; Grabley, S.; Sattler, I. J. Nat. Prod. 2008, 71, 689-692.

16. He, F.; Bao, J.; Zhang, X. Y.; Tu, Z. C.; Shi, Y. M.; Qi, S. H. J. Nat. Prod. 2013, 76, 1182-1186.

17. Rao, K. V.; Sadhukhan, A. K.; Veerende, M.; Ravikumar, V.; Mohan, E. V. S.; Dhanvantri, S. D.; Sitaramkumar, M.; Moses Babu, J.; Vyas, K.; Omreddy. G. Chem. Pharm. Bull. 2000, 48 559-562.

18. Morishima, H.; Fujita, K.; Nakano, M.; Atsumi, S.; Ookubo, M.; Kitagawa, M.; Matsumoto, H.; Okuyama, A.; Okabe, T. Japanese Patent, JP 06100445. 1994.

19. Hu, Q. F.; Zhou, B.; Huang, J. M.; Gao, X. M.; Shu, L. D.; Yang, G. Y.; Che, C. T. J. Nat. Prod. 2013, 76, 292-296.

20. Gooding, G.; Hebert, T. Phytopathology 1967, 57, 1285-1287. 